\title{
Merita V. Xhumari (2011). Pension Trajectories in Western Balkans. Three case studies: Albania, Macedonia and Kosovo 1990-2010. ERSTE Stiftung \& UNFPA, 158 pp. ISBN 9739928124241 (paperback)
}

\author{
REVIEWEd by DiRK HOFÄCKER*
}

The description of "greying economies" subject to "demographic ageing" has become a common phrase in both the academic and the public discourse on the major challenges that European societies are facing. Virtually all European countries have been witnessing a simultaneous appearance of an increase in longevity and a decline in fertility rates, resulting in a longterm increase in the relative (and partly also the absolute proportion) of people in older age groups. Particularly since the 1970s and 1980s, this trend has coincided with the increasing prevalence of early retirement, i.e. the withdrawal of older workers from active employment before reaching standard retirement ages. Only in more recent years, this "early exit" orientation has been replaced by policies supporting the late career employment of older workers.

The interplay of demographic ageing and early retirement is expected to shift the balance between social security contributors and recipients - a development that has been discussed particularly with regard to the future sustainability of pension systems. Already by the mid-1990s,

* Dirk Hofäcker, University of Duisburg-Essen, Essen, Germany 
International Journal of Ageing and Later Life

supranational organisations such as the World Bank called for a rearrangement of national pension systems from a dominant state-financed pension to a multi-pillar system, dividing pension responsibility among national governments, employers and individuals (World Bank 1994). More recently, there have been several initiatives on the EU level to promote this trend. Recent reports have taken account of the progress that single countries have made with regards to their pension systems (e.g. European Commission 2012a) and have formulated next steps for future reforms (e.g. European Commission 2012b). Yet, most previous studies have largely focused on developments in EU member states, i.e. a rather homogeneous group of countries, sharing basic similarities in terms of their social and economic development.

Countries located rather at the periphery of Europe, yet striving for future EU membership, have frequently been neglected in such comparative assessments. Merita Xhumari's book Pension Trajectories in Western Balkans sheds light onto this group of countries and thus fills an eminent gap in existing research. Her monograph intends to reconstruct the developmental trajectories of pension systems in three countries selected as case studies - Albania, Macedonia and Kosovo - in the early 1990s and the first decade of the new millennium. This purposeful selection of case studies is based on the assumption that while starting from a similar institutional heritage, the three countries have followed very different pension pathways after the system transformation. Methodologically, the study is based on a combination of desk research and document analysis with qualitative interviews and group discussions. Aggregate statistical figures from transnational data sets such as that of the OECD and ILO are added to provide additional quantitative evidence on the structure of labour markets or of demographic backgrounds.

Following a short introduction, Xhumari introduces the three country studies of Albania, Macedonia and Kosovo in single chapters, each of them following a parallel design, beginning with an overview of the situation of the respective country and its pension and relevant social security institutions right after the transition (i.e. in the early-1990s). Subsequently, developments in the post-transition period are described, focusing first on the first phase of (mostly parametric) pension reforms throughout the 1990s, followed by a discussion of reforms in the 2000s. Each chapter 
closes with a discussion of the major challenges that the three countries are currently facing.

In all of the three chapters, Xhumari succeeds to highlight the unique character of pension systems through a vivid but at the same time systematic description of nation-specific developments. Albania introduced a universal Bismarckian Pay-as-you-go (PAYG) system on a unified basis after 1993. It consists of a compulsory social insurance scheme - in which all rights acquired under the earlier pensions are preserved - and a voluntary supplementary scheme, as well as an additional supplementary social insurance that allows insured persons to either top up their benefits from the mandatory scheme or to continue their contribution record even in times of employment interruptions. The (largely parametric) pension reforms after 2002 kept the general structure of this system intact but lead to a "weakening of the link between contribution and benefits" (p. 28). Furthermore, increasing attention was focused on further developing private systems of insurance. This broadening of the basis for sustainable future pension systems was attempted in reaction to a situation in which foreseeable demographic ageing was accompanied by severe labour market strains enforced through high and long-term unemployment. Even though the parametric reforms aimed to strengthen "the financial sustainability of the system as a whole", they largely ignored "the social sustainability and adequacy of pensions" (ibid). In addition to these problems within the pension system, a large number of older Albanians are actually excluded from the pension system due to serious problems of insurance coverage, particularly among the self-employed and rural population. Future challenges for Albania are thus identified in the expansion of social security contributors, the guarantee of a sustainable minimum pension and the extension of second and third pillar pensions.

Developments in Macedonia initially exhibited similarities to the Albanian case, reflected in the introduction of a PAYG system in 1994 integrating earlier pension rights. Differences emerged in the early 2000s when - in response to demographic ageing and persistent labour market problems a second, full-funded defined contribution pillar was introduced to which contributors could switch while still being able to take advantage of first pillar payments. In 2005, private agencies were first allowed to manage such funds; in 2008, the government additionally laid the ground for a 
International Journal of Ageing and Later Life

voluntary third pillar based on private insurance. These reforms linked future pension outcomes more closely to market principles, justifying the description of Macedonia as exhibiting a "mixed pension system". The flipside of this broadening of the pension base, however, became apparent in 2008, when the global financial crisis led to a strong decline in pension fund returns. At the same time, the Macedonian pension system faces similar future challenges as the Albanian one: the under-coverage of self-employed and the erosion of its contributory base through low employment rates.

In historical terms, Kosovo deviates from the aforementioned examples, as its existence as an autonomous nation was established only in 2001, with full sovereignty only gained in 2008. Furthermore, Kosovo also represents a significant deviation to both Albania and Macedonia concerning its pension system trajectory. In 2002, the Kosovo government replaced the previous PAYG system by "a new liberal model" (p.91), relying on (i) a basic minimum pension for all residents irrespective of previous contributions, (ii) an additional fully-funded pension compulsory for all employees and (iii) a private voluntary pension. This radical re-orientation towards a minimum insurance supplemented by additional private opportunities seemed to be the only viable option in a situation where skyrocketing unemployment and widespread poverty called for the establishment of a pension at a basic subsistence level which at the same time was sustainable by limited public tax and social security contributions. Yet, when Kosovo gained independence in 2008, particularly the private pillar soon became subject to the adverse repercussions of the 2008 financial crisis so that the guarantee of a sustainable pension to prevent poverty remains among its major challenges.

Following the description of the nation-specific pension trajectories, Xhumari turns to the evaluation of their outcomes and consequences. In this part, she contrasts developments in the three country cases against the background of developments in other Balkan countries. "Poverty retirement" - i.e. the withdrawal from the labour market without adequate financial resources - is identified as a common problem of all these countries. Future prospects are meagre, given the still persistent crisis of national labour markets and foreseeable demographic ageing. Pension systems have been redesigned - either through parametrical 
reforms or through a more radical reorientation of their overall design to meet these challenges; yet their long-term social sustainability remains at stake. To rise to future challenges, the author suggests a mutual learning process, following the practice of the EU Open Method of Coordination $(\mathrm{OMC})$. Concrete suggestions for what each of the three sample countries could learn from the other two are developed in the final chapter, incorporating aspects of accessibility, governance, adequacy and financing.

Taken together, Merita Xhumari not only provides an excellent description of pension trajectories in the Balkans that is very recommendable for reading; her work also challenges many assumptions that are usually taken for granted in mainstream research on European pension systems. In such studies, it is often assumed that pension provision is largely universal, employment is - at least mostly - of a formal nature and pensions are generally financeable through taxes and social security contributions from employment. The study by Xhumari vividly demonstrates the dramatic consequences of what happens when such basic preconditions are missing. Under such conditions, even a rather favourable demographic background with only modest ageing trends and a qualified young labour force does not suffice to prevent severe pension consequences, such as high rates of poverty among the older population.

Given these specific preconditions in the Balkans, "standard recipes" for the reform of pension systems may prove insufficient. Yet, this is where the book still leaves some unresolved issues. Xhumari provides an excellent description of trends within her three sample cases, but does not attempt a more systematic explanation of why the three pension systems have developed in a specific way, and what factors may have been decisive for their national specificities (and the abandoning of other possible pathways). As a result, her conclusions for mutual learning may appear rather ad-hoc and less based on a theoretical model of pension system development. Yet, in a politically and economically still highly volatile and dynamic region such as the Balkans, such a model may be almost impossible to establish, and the best contribution any literature could make would be to give a systematic description of these dynamic trends that may become the starting point for future works. Without any doubt, the author has fully succeeded in providing this starting point. 
International Journal of Ageing and Later Life

\section{References}

European Commission (2012a). Pension adequacy in the European Union 2010-2050. Report prepared jointly by the Directorate-General for Employment, Social Affairs and Inclusion of the European Commission and the Social Protection Committee. Brussels: European Commission.

European Commission (2012b). An agenda for adequate, safe and sustainable pensions. European Commission White Paper. Brussels: European Commission.

World Bank (1994). Averting the Old Age Crisis: Policies to Protect the Old and Promote Growth. Oxford: Oxford University Press. 